University of Massachusetts Amherst

From the SelectedWorks of Shane P Hammond

2015

Complex Perceptions of Identity: The Experiences of Student Combat Veterans in Community College

Shane P Hammond 
This article was downloaded by: [Shane Hammond]

On: 29 April 2015, At: 17:54

Publisher: Routledge

Informa Ltd Registered in England and Wales Registered Number: 1072954 Registered office: Mortimer House, 37-41 Mortimer Street, London W1T 3J H, UK

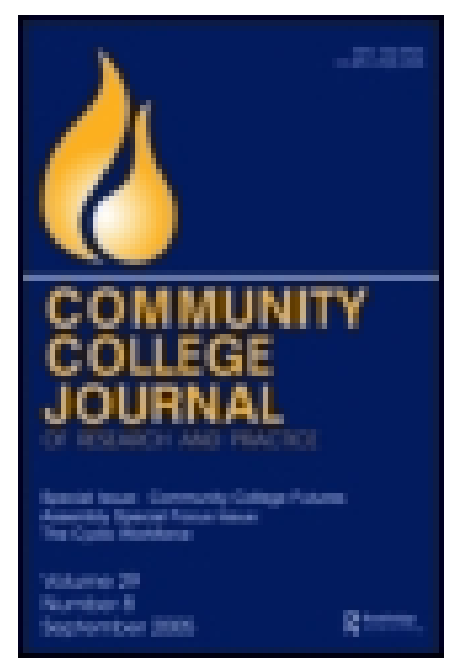

CrossMark

\section{Community College J ournal of Research and Practice}

Publication details, including instructions for authors and subscription information:

http:/ / www.tandfonline.com/ loi/ ucjc20

\section{Complex Perceptions of Identity: The Experiences of Student Combat Veterans in Community College}

Shane Patrick Hammond ${ }^{a}$

a Education Policy, Research and Administration, College of Education, University of Massachusetts, Amherst, Amherst, Massachusetts, USA

Published online: 29 Apr 2015.

Click for updates

To cite this article: Shane Patrick Hammond (2015): Complex Perceptions of Identity: The Experiences of Student Combat Veterans in Community College, Community College J ournal of Research and Practice, DOI: 10.1080/ 10668926.2015.1017891

To link to this article: http:// dx.doi.org/ 10.1080/ 10668926.2015. 1017891

\section{PLEASE SCROLL DOWN FOR ARTICLE}

Taylor \& Francis makes every effort to ensure the accuracy of all the information (the "Content") contained in the publications on our platform. However, Taylor \& Francis, our agents, and our licensors make no representations or warranties whatsoever as to the accuracy, completeness, or suitability for any purpose of the Content. Any opinions and views expressed in this publication are the opinions and views of the authors, and are not the views of or endorsed by Taylor \& Francis. The accuracy of the Content should not be relied upon and should be independently verified with primary sources of information. Taylor and Francis shall not be liable for any losses, actions, claims, proceedings, demands, costs, expenses, damages, and other liabilities whatsoever or howsoever caused arising directly or indirectly in connection with, in relation to or arising out of the use of the Content.

This article may be used for research, teaching, and private study purposes. Any substantial or systematic reproduction, redistribution, reselling, loan, sub-licensing, systematic supply, or distribution in any form to anyone is expressly forbidden. Terms \& 
Conditions of access and use can be found at http://www.tandfonline.com/page/termsand-conditions 


\title{
Complex Perceptions of Identity: The Experiences of Student Combat Veterans in Community College
}

\author{
Shane Patrick Hammond \\ Education Policy, Research and Administration, College of Education, University of \\ Massachusetts, Amherst, Amherst, Massachusetts, USA
}

\begin{abstract}
This qualitative study illustrates how complex perceptions of identity influence the community college experience for student veterans who have been in combat, creating barriers to their overall persistence. The collective experiences of student combat veterans at two community colleges in northwestern Massachusetts are presented, and a Combat Veteran Conceptual Identity Model to illustrate the ongoing negotiation of identity combat veterans experience while in college is introduced. Notable implications for future research and practice in Student Affairs are discussed.
\end{abstract}

Beginning with the first flood of veterans to higher education in 1945 following World War II and continuing to the two million veterans from the conflicts in Iraq and Afghanistan eligible for educational benefits under the Post-9/11 G.I. Bill (McBain, Kim, Cook, \& Snead, 2012), the academy has struggled with "who" student veterans are and "what" unique needs they present upon arrival to campus. Olson (1973) said, "When The Servicemen's Readjustment Act of 1944, commonly known as the G.I. Bill, was made into law, no one in their wildest imagination anticipated veterans would attend college in such numbers" (p. 602). The G.I. Bill also presented surprise to what educators expected veterans would be like versus what they turned out to be (Olson, 1973, 1974). Olson (1973) said, "The veteran generation established perhaps the most distinguished record in the history of higher education" (p. 604). Veterans were older, more mature, highly motivated, and tended to be better students than the general population (Olson, 1973, 1974). Initial governmental projections of veterans enrolling in colleges and universities drastically underestimated actual enrollments (Olson, 1974; Serow, 2004). Serow (2004) suggested the G.I. Bill did not necessarily create a broader demand for higher education, but merely subsidized those who would have attended even without federal support. Titus (1944) said the complex relationships between veterans and college would require an intimate, institutional understanding of these needs if veterans were to be successful in college.

Sixty-five years later, Ackerman, DiRamio, and Mitchell (2008) introduced a contemporary renewal to Titus's (1944) statement about combat veterans when they said, "The experience of war makes those who fight a special group within the general population" (p. 5). Similar to veterans of the post World War II era, student veterans are returning to higher education from

Address correspondence to Shane Patrick Hammond, University of Massachusetts, 813 North Pleasant Street, 124 Furcolo Hall, Amherst, MA 01003. E-mail: shammond@umass.edu 
contemporary conflicts in record numbers, gaining access to significantly more institutions, such as the vast system of community colleges, beyond the exclusive institutions of the 1940s. Student veterans are financially independent, disciplined, and goal oriented, yet also present as a population at risk for not persisting to graduation (Kelley, Smith, \& Fox, 2013). Student veterans bring their own array of unique and diverse backgrounds and life experiences to the college campus. Loss (2012) contends the expanded psychological understanding of students in the academy is critical to our collective knowledge of the history of organized higher education in the United States and is deeply rooted in the study of student veterans such as those in the post World War II era and beyond. Therefore, the resurgence of this population of students in higher education compels educators and researchers alike to better understand these students as complex individuals with multidimensional coconstructed identities.

The National Center for Education Statistics (NCES) reports veterans are 21.2\% less likely than nonveterans to attain a bachelor's degree and are 4.1 percentage points more likely to drop out of college without obtaining a degree of any sort (Kelley et al., 2013). Common injuries to deployed Operation Enduring Freedom and Operation Iraqi Freedom service members include physical injuries such as amputations and traumatic brain injury (TBI) and psychological "hidden" injuries such as posttraumatic stress disorder (PTSD) or depression (U.S. Department of Veterans' Affairs, 2010). The National Survey of Student Engagement (2010) reports about one in five combat veterans in college disclosed having at least one disability, twice the number of nonveterans. Given that the challenges associated with attending college are heightened for students with a disability, a comprehensive understanding of the experiences of student combat veterans is critical to informed practice.

According to Cate (2013), "The 2010 National Survey of Veterans and the American Community Survey report a potentially large proportion of student veterans, approximately $30 \%-40 \%$, not completing their postsecondary programs" (p. 1). This should be a cause for continued concern in higher education and is testimony to the need of further research, such as this study, to better our understanding of student veterans in efforts to improve upon their success in college. Cate (2013) continues saying, "research into potential causes for student veterans' withdrawal from college should be explored, so that student veteran post-secondary completion rates can be raised" (p. 1).

Contemporary studies, such as those conducted by Ackerman et al. (2008), Cook and Kim (2009), Rumann and Hamrick (2010), and Livingston, Havice, Cawthon, and Fleming (2011), have focused primarily on the veteran transition to higher education and relied heavily on the work of Schlossberg's (1984) theory of adult transition for study design and conceptualization of findings. Few empirical studies applying theories of identity development to combat veterans exist (DiRamio \& Jarvis, 2011; Rumann \& Hamrick, 2010). Thus, findings from this study advance the conversation related to veterans in college. They also provide valuable insight to researchers and student affairs educators regarding the social psychological impact of combat and how veterans' service directly influences their personal identity, thus shaping their overall experience in college.

\section{RELATED LITERATURE}

Identity can be thought of as a set of meanings that define who one is based on individual experiences, what role one holds in society, which group one belongs to, or which characteristics 
make one unique (Burke \& Stets, 2009). "People possess multiple identities because they occupy multiple roles, are members of multiple groups and claim multiple personal characteristics, yet the meanings of these identities are shared by members of society" (Burke \& Stets, 2009, p. 3). William James (1890) first theorized people have as many "selves" as we have interactions or experiences with others. We take on many identities over the course of a lifetime, and at any point in time, these identities could be activated (Burke \& Stets, 2009). Student combat veterans are often thought of as holding multiple roles in our society: the role of veteran, civilian, student, brother, sister, spouse, and/or parent, etc. Results of this study illustrate the phenomenon of taking on a particular identity for student combat veterans in their interactions with students, faculty, and staff on their campuses and a contextual activation of this identity.

Dominant frameworks for past research on student involvement and role identity have not taken into account the complexity of maturation and identities shaped by life experiences of adult learners (Kasworm, 2003; Kasworm, Polson, \& Fishback, 2002). According to Jones and McEwen (2000), although past research has often considered differences according to gender, age, or other social conditions, models for intersecting social identities have not been frequently researched or tested. If veterans are continuously renegotiating their own personal identity as they transition from a military environment to college (Rumann \& Hamrick, 2010), a combat veteran could be seen as a student in one context, but also may simultaneously be negotiating multiple identity roles of combat veteran, citizen, or peer.

I chose the conceptual identity framework developed by Gee (2000) and Hecht's (1993) communication theory of identity (CTI) to help guide this study. Gee's theory was originally developed to address social and contextual changes in the contemporary world that may cause people to form "multiple, changing and fluid identities" (p. 121). In his theory, Gee said, "When any human being acts and interacts in a given context, others recognize that person as acting and interacting as a 'certain kind of person' or even as different kinds at once" (p. 99). This conceptual model on identity is built upon four perspectives on what it means to be a "certain kind of person:" nature-identity, institution-identity, discourse-identity, and affinity-identity (p. 99). For the purposes of this study, the certain kind of person would be student veterans who have enrolled in higher education after one or more combat deployments. I also included Hecht's (1993) CTI given its congruence with Gee's (2000) conceptual framework and its illustration of how the frames of identity in the framework may both complement and compete with each other, demonstrating the complex, fluid nature of identity. According to CTI, identity is inherently a communicative process in which messages and values are exchanged and is located within "four distinct frames: (1) within individuals, (2) within relationships, (3) within groups, and (4) communicated between relational partners and group members" (Orbe, 2004, p. 134). These frames should be thought of as permeating all discussions of identity, they are not static or linear in nature (Hecht, Jackson, \& Ribeau, 2003), and they should be studied simultaneously to demonstrate ways in which the different frames of identity may be complementing or competing with each other at any given time.

\section{Theoretical Significance}

This research provides the opportunity to reflect upon previous contemporary scholarly inquiry, reconsiders the applicability of prior theoretical correlations to the student population, and 
introduces alternative ways of conceptualizing the lived experiences of combat veterans in higher education. Ackerman et al. (2008) first introduced Schlossberg's theory of adult transitions (1984) as a theoretical lens to gain insight into the potential short- and long-term effects of a student veteran's transition from the military to the college classroom. The model was not adapted for student veterans, but rather applied to the research as a guiding theoretical frame with the assumption that being called to active duty with the prospect of combat qualifies as a major transition, disrupting existing routines and relationships (Ackerman et al., 2008). In their findings, the authors noted that emergent themes from the qualitative analysis "fit neatly into the 'Moving In, Moving Through, and Moving Out' model” (Ackerman et al., 2008, p. 80); and consequently, the authors made recommendations for future practice based on those same emergent themes. Although this study was significant and marked the reemergence of attention to student veterans and contemporary exploration, it is difficult to imagine the lived experience of any participants fitting neatly into a particular theory despite how comprehensive the theoretical framework presented. I argue that movements as part of an overall transition for combat veterans are unlikely to be linear or to contain distinct beginning or end points for each phase of that transition. Rather, the movement is more fluid and not necessarily concrete for the individual experiencing transition. Therefore, this calls into question the likelihood of any individual fitting neatly into a predefined category of transition, given the complexity of the individual's own lived experiences and the unpredictability of contributing factors to that transition.

Rumann and Hamrick (2010) built upon the earlier work of Ackerman et al. (2008) by incorporating the $4 \mathrm{~s}$ system of factors (situation, self, support, and strategies) as developed by Goodman, Schlossberg, \& Anderson (2006) into their theoretical framework and analysis. Rumann and Hamrick (2010) suggest student veterans may be actively processing their military experiences while simultaneously negotiating their own personal identity as part of their experience while in college. In their discussion, they said, "Studies overtly focused on student veterans' sense-making related to multiple dimensions of identity could reveal a great deal about how student veterans construct and achieve a more complex sense of self that incorporate their experiences of the social identities of service-member and veteran" (p. 454). The research of Rumann and Hamrick (2010) marks an important crossroad in the contemporary research and a significant next step towards a greater understanding of this population; yet, their study was limited to only six participants, calling for the further empirical research presented here.

Livingston et al. (2011) investigated student veterans' navigation of college reenrollment, and the emergent themes and analysis presented in their results provided the first transition model tailored specifically to student veterans. In their results, Livingston et al. (2011) suggested a notable gap in the research related to how student veterans navigate identity renegotiation upon their transition and how the perception of their own identity may influence their experience in college. DiRamio and Jarvis (2011) expanded upon this recommendation by devoting a chapter of their work to a discussion of identity: veteran, civilian, and student. Theories of identity development were applied as a means of understanding the emergent population of student veterans on campus; however, the authors noted that little empirical evidence exists to support the ideas they presented. DiRamio and Jarvis also noted that future research related to the implications of identity development for students with military experience could be useful to developing a better understanding of 
this population of students on community college campuses. This study and its results are based upon this gap in the literature.

\section{METHODOLOGY, METHODS, AND DESIGN}

This research study utilized a qualitative methodological design and a constructivist paradigm. This methodological approach provided the opportunity to add to the existing body of knowledge related to student veterans who have experienced combat. It also contributed to a greater theoretical understanding of the phenomena of identity for combat veterans enrolled in college. The study employed critical components of inductive grounded theory methodology (Glaser \& Strauss, 1967) including "constant comparative analysis and theoretical sampling" (Strauss \& Corbin, 1998, p. 21). Participant interviews served as the primary means of data collection for the study.

\section{Design and Data Collection}

Two rounds of semistructured interviews were conducted for each participant to generate data to help answer the primary research question: How do combat veterans perceive their own identity and what influence does this have on their experience as college students? I utilized a semistructured format for flexibility in the interview protocols. Both interview protocols were formulated using Hecht's CTI (1993) and Gee's (2000) conceptual model of identity and derived to answer the research question and explore gaps in the existing literature. The two theories present contravening elements to the other. Hecht (1993) introduces frames of identity that focus on how identity emerges from an individual based on relationships, whereas Gee (2000) describes four ways to view individual identity as shaped by social-contextual interactions with other individuals, group affiliation, or shared experiences. The utilization of both frames enabled me to consider the relevance of each to participant responses while allowing for opportunity to critically reflect upon the distinct differences in each lens of inquiry. Interviews were conducted in person and audio-recorded with the participant's consent for ease of transcription and to allow me to actively listen to the participant responses.

\section{Research Site and Respondent Selection}

I chose two purposefully selected two community colleges located in northwestern Massachusetts for this study. Research site one has an enrollment of approximately 3,000 full/part-time students, and research site two has approximately 4,000 full/part-time students. The demographics of these two campuses promoted typicality of the setting, heterogeneity of the sample, and illustrative comparisons of participants at each site (Maxwell, 2005). The participants I selected for interviews self-identified as combat veterans, having been on at least one combat deployment prior to enrollment at one of the selected research sites during the 2011-2012 academic year. I utilized both purposeful and snowball sampling (Maxwell, 2005) to identify eligible participants at each institution. Following Institutional Review Board approval, I made initial contact with prospective participants via email and 
telephone. From the population of students at both institutions, I chose a sample of 19 combat veterans for the study.

\section{Data Analysis}

For data collection and analysis, I employed a constant comparative analysis (Strauss \& Corbin, 1998) approach and continued until it was determined that theoretical saturation had been reached and a grounded theory was fully integrated (Birks \& Mills, 2011). Analysis of the data consisted of the three levels of coding recommended by Strauss and Corbin (1998): (a) open (emic) coding, (b) axial coding, and (c) selective (etic) coding. The initial coding occurred as a reflexive activity, with my ongoing reflections about the analytical decisions I made early in the analysis (Strauss \& Corbin, 1998).

\section{Respondents}

I selected 19 individuals to participate in the study. To ensure proper confidentiality, participants were asked to choose a pseudonym to be used when referring to them throughout this article. Participant profile information is listed in Table 1. Seventeen participants identified as male, 2 as female, and all 19 of the participants self-identified as White/ Caucasian. Limitations related to the race and gender imbalance of the selected participants is significant and will be discussed later in the paper. Participants ranged in age from 22 to 49 years old. The mean age of participants was 31 years old. Participants represented four branches of the United States military: Army, Navy, Air Force, and Marines.

TABLE 1

Participant Profiles

\begin{tabular}{llll}
\hline Participant & Age & Military Branch/\#Combat Tours & Semester Enrolled \\
\hline John & 23 & Army/1 & Spring '08/Fall '11 \\
Michael & 29 & Marines/1 & Spring '09/Fall '11 \\
Miles & 28 & Army/1 & Spring 2011 \\
Blacksheep & 28 & Air Force/1 & Fall 2010 \\
Frenchy & 23 & Army/1 & Fall 2011 \\
Steve & 27 & Marines/2 & Fall 2011 \\
M. Autumn & 28 & Army/1 & Fall 2010 \\
Vinstigator & 37 & Air Force/multiple & Fall 2010 \\
Hobo & 25 & Air Force/1 & Fall 2010 \\
Bobby & 30 & Army/1 & Fall 2011 \\
Joe & 29 & Army/1 & Fall 2010 \\
Master Sergeant & 49 & Army/1 & Fall '96/Fall '11 \\
Peter & 43 & Army/1 & Fall 2009 \\
Jason & 33 & Marines/1, Army/1 & Fall 2010 \\
JP & 39 & Navy/1 & Fall 2010 \\
Andrew & 24 & Air Force/multiple & Fall 2008 \\
Sandy & 41 & Marines/1 & Fall 2011 \\
Nate & 27 & Army/3 & Fall 2010 \\
Adam & 22 & Army/1 & Fall 2008 \\
\hline
\end{tabular}




\section{FINDINGS}

For the 19 participants in this study, transition from the military after one or more combat tours of duty and subsequently enrolling in college made their transition from the military particularly complex. Participants described the process of transition and adaptation to both civilian life and life on a college campus as fluid and ongoing with no definitive end to that transition. After careful analysis and consideration of the qualitative data collected during interviews, my own fieldwork and reflective memos, and feedback from peer review, four salient themes representing the collective experiences and perceptions of the participants were identified.

\section{Perception of Self}

Veteran as part of core identity was ever-present for the participants, shaping who they are and their lens on the world around them. In fact, the majority of participants felt strongly that being a combat veteran was a significant part of their core identity and an important aspect of who they were as individuals in the process of making meaning in their everyday lives. Put simply, Miles said in his answer, "First and foremost, I am a veteran." Andrew said, "I mean how does it leave you? It's who you are; it's who you become." Master Sergeant said, "I'm very proud and was honored to serve. It's extremely a very intricate part of who I am today-how I see the world, how I carry myself, what I represent, what I did for this country." Similarly, Jason said, "It's who you are."

Connected to perception of self and core identity, more than half of the participants selfidentified as struggling with some level of Post Traumatic Stress Disorder (PTSD) after combat. Participants discussed everyday occurrences on campus, such as activity in and out of the classroom, classroom seating orientation, crowds of students crossing campus between classes, and everyday noises, that triggered the combat veteran inside. These triggers frequently caused them to be distracted from their work. Blacksheep said, "There's no bunker in my house, but it's just ingrained into your DNA, so, I mean, little things like that, maybe something as simple as explaining to the student, 'Please don't bang on the desk." Andrew said, "I'm very aware of my surroundings and I think I will be till the day I die just because of what's been drilled into me. I can go into a crowd and pick out different behaviors from people and identify who needs to be watched or not watched." When asked if he thought this hyper-vigilance was distracting and influenced his experiences on campus, Andrew said, "It does. I mean you think about it, you're trying to listen to what the instructor is doing and your mind is somewhere else." JP, who selfidentified as struggling with severe PTSD said, "During class you're in 2,000 different places. You're still trying to listen to what they're saying and comprehend it, but you're also making sure that nobody around you is gonna do anything goofy."

John talked about how it felt to be on a college campus and said, "You're still kinda looking over your shoulder. I experienced that a lot in my first semester when the classes were getting out and there's a lot of-there's a big crowd." Participants spoke of how easily it could be for them to be triggered on campus. JP said, "If you're triggered, you're triggered. And it's anything-it can be a smell, a taste, whatever. I can be triggered by anything-a noise in a classroom can trigger something familiar."

All of the participants acknowledge that their experiences in the military serving on combat deployments influenced how they see themselves and how they make meaning in their everyday 
lives. In a powerful statement, Jason spoke of being profoundly changed on a cellular level due to his experiences. He said, "Yeah, that's-I mean, I've grown up because of it. That's who you are. It's in my cells. Yeah, you know, it becomes a part of you. And just in life, not just with school. In life in general, you just got a certain glare to yourself, you know?" Sandy continued by saying: "I'm completely different from when I was back then before I went in."

\section{Perception of Others}

Identity as a combat veteran has not only contributed to how veterans perceive themselves, but how they perceive nonveterans. Participants perceived younger students as being immature and less experienced, appearing less disciplined, and having a perceived lack of appreciation for their college education. JP said:

People coming back from war have seen and done a lot more than say the average 17, 18-year-old, 19 -year-old that comes in here and thinks they know all about life. And that pisses you off 'cause you're like, "Look man, you have no idea."

Andrew added:

It's hard for me to talk to someone that's fresh out of high school and relate to them, because they're fresh out of high school. They haven't lived life yet. I haven't lived life fully yet, but I lived the military life, and someone fresh out of high school has no clue what that is.

Jason spoke of an innocence he perceives surrounds him on campus when he said this:

Well, you look-say if I look around the classroom, I see all these young faces. I mean, I really, truly feel I have more miles backwards than they have frontwards just because of experience, just overall general life. Kinda see an innocence in everyone around you.

Participants spoke regularly of their perception that other students, younger students in particular, lacked the discipline each of them saw as an integral part of the college experience. Vinstigator said:

I say kids, these young adults text messaging or having a side bar conversation while the professor is speaking, which is of course you know the decorum of ethics and etiquette in the classroom. And it frustrates me as a military guy. They need discipline in the room.

Blacksheep added, "I really can't tolerate kids who, you know, 19-20 years old who just don't understand, 'You're in the classroom to learn." When asked about how distracting these types of feelings can be for him while in school, Adam added, "Oh, like you wouldn't believe. It drives me nuts. It takes a lot of concentration on my part to keep my attention on the teacher." Blacksheep added:

It really takes away from the educational experience for me. I look at them, and I'm like I earned the right to be here. I fought to be here and it's so clear you don't want to be here. You're in school, and it's a privilege. Don't squander it. Don't sit there and waste my time. I paid with blood, sweat, and tears for my time here. 
Participants in this study regularly perceived themselves as more mature, more disciplined, and more experienced - and their younger peers as immature, less disciplined, and lacking an appreciation for their education.

\section{Inferred Perception of Self}

For participants, there was also an apparent inferred perception of self based on the interactions participants had with nonveteran civilians in and out of the classroom. Described were feelings, or microaggressions, of being targeted or labeled in everyday circumstances in college due to the stigma or misconception of combat veterans, especially when inappropriate questions or interactions with nonveteran students occurred. JP called the "worst question ever:" "Have you ever killed anyone?" The question itself, posed in different contexts with other students and asked of every participant at one time or another, prompted various reactions from participants in the moment such as anger, frustration, and avoidance. JP explained how it feels to be asked this question:

Yeah, I hate that question, 'cause it's-no one wants to relive what they went through. They have a hard enough time already, trust me. 'Cause PTSD, you trigger and you see it. You feel it; you smell it. It's rough.

Sandy said in his description, "Yeah, I think so. It's just yeah, they think that that's you go in the military and that's what you do. You go and kill people. That's not always, you know, we'd rather not." Michael talked about the personal nature of being asked the question and a feeling of being labeled in the moment the question was asked. He said, "I mean, that just-so, the perception there that we were just killers was definitely-it was somethin' that-that hit home. I was like, 'This isn't somethin' I wanna talk about."'

Steve spoke of a fear of being labeled and expressed an awareness of labels associated with combat veterans. He said:

So, students perceive us all different ways. Like, I've been told that oh, you're probably a baby-killer and this and that. There are people that judge you automatically when they find out that you're in the military. So what do we do? We just take ourselves out of the equation.

Nate talked about the misconception people have of combat veterans, and said:

Especially when it's so derogatory towards some of the things I've done. Have I killed people? Yeah, you're damn right I have. But yeah, you didn't learn about the school I built-helped build. The soccer field we made for the kids.

M. Autumn said simply, "I don't even need a recognition or anything, I just don't think people should hate vets. They just need to be like-they did something good and thank you, that's all."

Jason talked about the filters he has up in class or on campus in an effort to not have to discuss his experiences as a combat veteran, in an effort to avoid uncomfortable situations. $\mathrm{He}$ said: "I don't wanna upset anybody. So that, you do put a wall up. I'm just gonna say, mind my own business, learn what I can. Keep a smile on my face." Bobby expressed similar feelings when he said, "I don't really tell people that I'm in the military. I'd rather just fly under the radar, do my thing." 
Participant responses suggested that they carried an inferred perception of self as emotionally and/or mentally unstable due to their combat experiences due to these regularly occurring microaggressions on campus. Interestingly, this appears to stem from conscious and unconscious messages from nonveteran civilians embedded in these perceived aggressions. When Joe spoke of his return from combat, he said, "It seems like when you come back everybody just wants to see how crazy you really are." Frenchy talked about the perception he thinks people may have of him, but also his sense of self in the context of what he went through. He said:

You can say I'm messed up in the head. You can say any of 'em are, but, eh, it's normal for what we went through. I don't wanna be seen as the crazy, angry, "you gotta watch out for him."

Michael said, "I don't know I just-I felt like I wanted to distance myself and not really-you know, I didn't want to give my opinion and make people - oh, he's just a crazy war vet." In a powerful statement, John talked about the apprehensions he held of reading his English paper about combat aloud in class to others who are not veterans. "It was part of the dehumanization part. Um, they might look at me like a monster."

Although not every participant spoke directly about the perception of being "crazy" because they were a combat veteran, each of them spoke about being seen differently due to their veteran status - an inferred perception of combat veterans as thoughtless killers lacking emotion and rational decision-making based on the inappropriate questions and behaviors of their non-veteran peers. This inferred perception of self appears to be closely correlated to the experience of the participants as college students.

\section{Connections to Other Veterans}

Equally important to the delicate balance of core identity and perception of self appears to be the strong connection participants feel towards other combat veterans in and out of the classroom. Andrew illustrated this when he said, "Being in the military, it's different. It changes your thinking, the way you live, so it's, to me, we're all the same. I mean, that's - it's the brotherhood. I mean, I don't care what branch you're in, it's brotherhood.” M. Autumn said:

I mean, even if we haven't even gone- even if they haven't deployed or deployed to the same place as me, it's like there's somebody who just knows what you've gone through. And you don't have to explain little details. And they don't ask uncomfortable questions.

Participants spoke directly about the comfort level they feel around other veterans on campus and the depth of this bond. Jason said, "When you're around other vets, it kind of, it's that camaraderie still. It's a comfortable zone, you know? Miles said, "And that feeling is-you know, and you can-it just kinda just makes everything like better, you know. Like, you don't really-I don't know, you just understand each other, you know what it's like, you know." This bond appears to create a heightened sense of awareness of other veterans and their well-being on campus. John spoke of what he can see in other veterans, what they may see in him, and how they are able to take care of each other in the moment. He said: "Um, sometimes they can see. They-they-they've been back long enough, they're-or they know what you're going through, so they can see when you're having a hard time. They'll snatch you up, take you to the side." Blacksheep said, "But when there is another veteran in the class, and you do know it, you kind of rely on each other for a little bit." She added: 
If I know you're a veteran, and you know I'm a veteran, we'll kind of keep an eye on each other, even if we don't ever talk to each other, you still keep an eye out for each other. You always look out for them even if you kind of stay three steps away.

Connections to other veterans appear to be woven tightly into the fabric of the participants' lived experiences during and after their time in the military. Seventeen of them spoke of the camaraderie and brotherhood that exists between all veterans, regardless of rank, branch or conflict, based on their training, service in the military. and shared experiences of combat. This connection runs deep and provides these combat veterans with a significant validation of self and membership in a uniquely defined collective of individuals much larger than themselves.

\section{LIMITATIONS}

Given that this study explored the lived experiences of participants and how they perceived their own identity, it would not be reasonable to assume that the experiences of participants in this study were representative of student combat veterans at other institutions. Most notably, participants were predominantly male and all participants identified as White/non-Hispanic, with no apparent representation of minority or underrepresented student populations. Thus, the theoretical saturation and resulting Combat Veteran Conceptual Model (Figure 1) represents only White, predominantly male student combat veterans. This limitation cannot be overstated given the complexity of gender, racial, and ethnic identity as potential compounding factors related to overall perception of one's identity and self-construct. Additionally, it would not be possible to compare the impact of combat on the participants equally, nor would it be reasonable to assume that the number of combat tours or length of a deployment is directly correlated to a participant's perception of identity or lived experience. Given that the participants acknowledged a greater comfort level interacting and communicating with other veterans during the study, my status as a

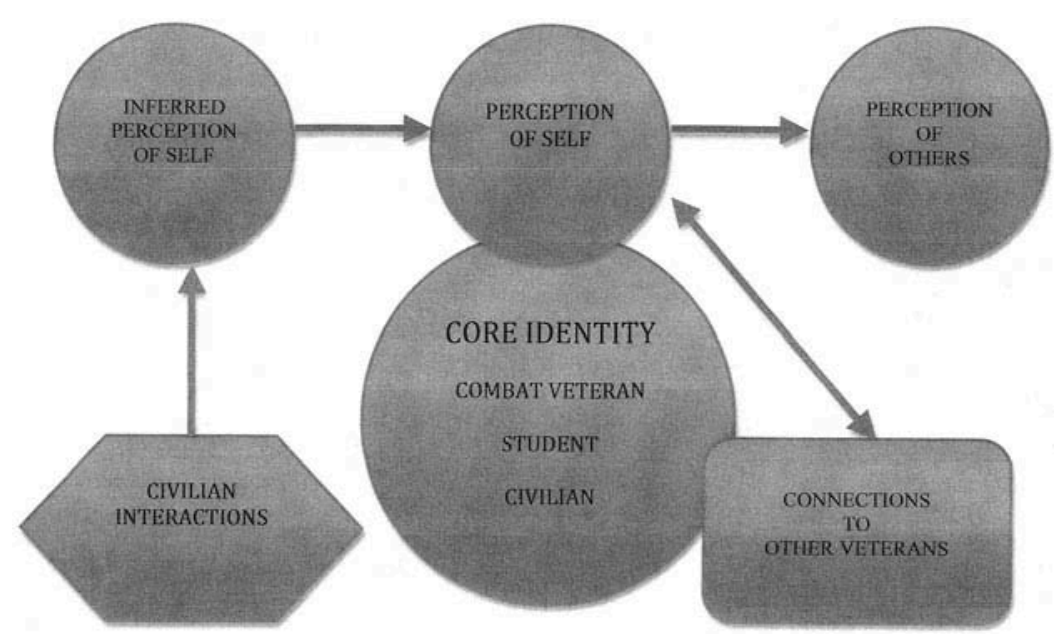

FIGURE 1 Combat Veteran Conceptual Identity Model. 
nonveteran may have indirectly influenced the depth and breadth of the data being collected. Finally, data from this study are not assumed to be generalizable to the larger population of student veterans in higher education because of the qualitative nature of the research and inquiry guiding the study.

\section{DISCUSSION}

This study focused on combat veterans in community college, a distinct subset of the larger population of veterans entering colleges across the country. The Hecht (1993) CTI was significantly useful when applied to the student combat veterans in this study; it provided the necessary scaffold to structure the interview protocols in a way that allowed me to develop a deeper understanding of how combat veterans reveal or enact their own personal identity to others. When viewed in conjunction with the conceptual lens of Gee's (2000) model, I was able to develop the core components of the Combat Veteran Conceptual Identity Model (see Figure 1) and consider the relationships between those components and the importance of how they interrelate with each other.

The works of both Hecht (1993) and Gee (2000) were well suited to the study of combat veterans, how they perceive their own identities, and how this perception impacts their overall experience in college. Both frameworks provided an important opportunity to explore the complexities of multiple identity negotiation for combat veterans inside and outside the community college classroom. And each of the themes that emerged from the data analysis appears to be actively present for the participants and strongly correlated to core identity. Environmental factors, interpersonal contexts, and the participants' own evolving sense of self appear to influence their ongoing negotiation of identity as combat veterans, students, and civilians. This apparent negotiation and the intersection of each of the themes with core identity are illustrated in the model.

The Combat Veteran Conceptual Identity Model advances the understanding of student combat veterans, offering a conceptual framework that represents a combat veteran's core sense of self and introducing contextual factors that influence their experiences in community college. Since the negotiation of combat veteran to civilian to student is more fluid rather than linear in nature, the Combat Veteran Conceptual Identity Model, informed by the emergent data and guiding frameworks of Gee (2000) and Hecht (1993), represents an alternative way of understanding how participants perceive their own identity and how that identity is influenced by external factors and relationships.

All 19 participants see themselves as veterans and acknowledge that their experiences in combat have profoundly shaped who they are as individuals today. Notably, participants do not see this part of their core identity diminishing over time, and the negotiation between combat veteran, citizen, and college student is ever-present while enrolled in college. This correlates to Hecht's (1993) first frame of identity, the personal frame, whereby identity is the result of a person's self-cognitions, self-concept, and sense of well-being (Golden, Niles, \& Hecht, 2002). This phenomenon also proves similar to the nature-identity discussed by Gee (2000), whereby the source or "power" over identity is a force over which there is no control (for example, race or gender), unfolding through a natural process of development rather than from societal factors. This could be thought of as one's core identity or perception of self. 
How participants perceive others, in particular their younger peers in college, appears to be deeply rooted in how they see themselves as veterans and individuals since their combat deployment(s). Participants' perception of others often translates into frustration or distraction on campus or in the classroom, an inability to concentrate, or self-isolation from others. These resulting factors seem to be most pervasive in the classroom environment, proving to be a significant distraction and disruption to the learning environment for some. This type of disruption may contribute to poor performance in the classroom, breaks in attendance, and ultimately, withdrawal from the institution if not addressed early in their enrollment. This resulting perception of others is connected to Hecht's (1993) second frame, "within relationships," involving the enactment of identity to others, focusing on the messages a person sends to express his/her own identity. This is associated with Gee's (2000) institutional-identity, wherein the source of power is not nature, but an institution, with the power working as levels of laws, rules or traditions. For veterans, I-identity could be that of student-veteran, representing both the alignment and conflicts associated with the laws, rules, and traditions of the military versus those in academia, thus influencing judgment of their peers perceived as non-military.

Participant responses suggested an inferred perception of self based on their interactions with nonveteran civilians in and out of the classroom or other social contexts related their experiences in the military. This inferred perception fell into two distinct categories: an inferred perception of being a "killer" or a perception of emotional/mental instability. This perception often caused participants to selectively conceal their identity as a combat veteran in class or when conducting an assignment and to isolate themselves from nonveterans. Similar to Gee's (2000) discourseidentity, where power rests with the discourse or dialogue of other people as it relates to the subject, this perception of self illustrates Hecht's third frame of the CTI, which is a relational frame, focusing on how identity emerges through our own interactions with others or "within groups." The perceived stigma associated with emotional distress or hidden injury such as PTSD contributed to an inferred perception of self that emerged for participants, influencing the infrequency with which they reached out for help or registered with disability services for accommodations in the classroom. This is significant, given that a lack of proper accommodations in the learning environment is known to increase the risk of student departure, potentially impacting overall retention rates for veterans on campus.

The connection combat veterans feel to other veterans is a significant factor in their experience in college. Knowing other veterans positively contributed to the participants' greater sense of comfort and community in college, and the relationships they developed with other veterans promoted conditions for academic success throughout their enrollment such as peer mentorship and support. This shared connection represents Hecht's (1993) fourth and final frame in the model, a communal frame, occurring in the context of a larger community or group, where identity is held in the collective or public memory of a group that, in turn, bonds the group together (Hecht et al., 2003). Possessing a group identity that represents a shared identity of all of its members mirrors Gee's (2000) affinity-identity, where the group has requisite experiences or shared norms.

The Million Records Project report, released in May, 2014 by The Student Veterans of America (SVA), in conjunction with the Department of Veterans Affairs and the National Student Clearinghouse, provides a high-level overview of what is purported to be veterans' progress in achieving education. It underscores the need for ongoing efforts to promote research and informed practice related to veterans in higher education (Minnis \& Hammond, 2014). This 
research study advances an important conversation related to why veterans are completing or not completing higher education and suggests important factors influencing their enrollments and persistence to completion.

\section{OPPORTUNITIES FOR FUTURE RESEARCH}

As part of the next wave of contemporary research related to student veterans in college, this research provides an important building block of empirical evidence related to identity. It introduces the Combat Veteran Conceptual Identity Model (CVCIM) as a means to focus the theoretical understanding of combat veterans in higher education by considering their experiences through a lens of identity. Future testing of the model will allow for improved understanding of the relationships presented in the components of the model and focus the theoretical conversation related to this population of students. Given the limitations of this study related to race and gender, future testing and analysis of the conceptual model presented in this study should reflect the diversity of race, ethnicity, and gender in the both the U.S. military and the student veteran population across the academy today.

The strong sense of veteran status being part of core identity and the significant connections to other veterans expressed by participants suggest that individual identity becomes secondary to the identity of the larger group, potentially influencing social integration as a combat veteran transitions from the military to civilian life and college. The CVCIM also suggests a dynamically fluid influence on identity as demonstrated by the personal perception of self and inferred perception of self, informed by interactions with nonveteran civilians and the deep connection they feel to other veterans. Investigating the inverse relationships that may exist between components of the model will provide for a better understanding of personal identity for student combat veterans and help to inform improvements to overall practice.

Future research related to the social systems for student veterans at commuter colleges versus a residential college or university will provide valuable insight into the enrollment experience of student veterans and the impact typicality of setting has on their persistence, retention, and overall success. Additionally, future quantitative research related to student veterans will complement the growing body of qualitative research devoted to this population. Specifically, longitudinal studies focused on the overall persistence and success of student veterans, including graduation rates, will provide a better picture of outcomes for student veterans at institutions of higher learning throughout the country.

\section{IMPLICATIONS FOR PRACTICE}

The results of this study provide notable implications for future practice in higher education and underscore the distinct experiences of student veterans who have experienced combat and the challenges they face in college as a result of those experiences. Some reports have estimated that the student veteran first-year-postsecondary dropout rate is $88 \%$ (Briggs, 2012; Wood, 2012), suggesting poor retention rates for student veterans in postsecondary education. The Student Veterans of America have stated the following: 
National data on student veterans is difficult to find, simply because no federal department has been tasked with the collection and analysis of data regarding student veterans or their academic outcomes. This is a problem for policy makers and stakeholders who rely on research to make informed decisions. (Cate, 2013, p. 1)

This lack of national data and the on-going need of supports for student veterans warrant more studies - such as this one - that offer insight into the veteran experience and recommendations for improvements to practice in student affairs.

Many student veterans have reported they feel isolated from their peers on campus and also feel set apart from the faculty and staff in the academic environment (Kelley et al., 2013). This sense of isolation could lead to decreased enrollment and present a risk to persistence if not addressed. Professional development opportunities for staff and faculty that remove preexisting stigmas of combat veterans will provide a greater understanding of this population, thus giving them the ability to better meet needs as they arise. Student affairs practitioners should also consider incorporating student programming into the cocurricular schedule that includes an opportunity for nonveteran students to learn more about their veteran peers and build a greater awareness of this population of students on campus. Such programming will not only reduce feelings of isolation for student combat veterans, but it will also reduce the risk for uninformed interactions between student veterans and their peers and prevent the microaggressions outlined in the findings of this research that create a negative perception of self.

Student veterans are actively seeking an educational environment that gives them the tools they need to be successful (McBain et al., 2012). Creating a detailed enrollment plan that guides student veterans through the enrollment process and connects them to dedicated academic advisors, perhaps veteran peer advisors, trained to work with them and deploy specific intrusive advising and early intervention methods will increase their persistence and opportunity for academic success. The connection veterans feel towards one another should be nurtured and encouraged by administrators in higher education. This can be achieved through the establishment of dedicated space and programming such as veteran peer enrollment counseling, support services referral, tutoring, and cocurricular activities that promote academic success and retention for veterans.

Social supports in the military can be taken for granted, given that those relationships are often forged in extreme circumstances such as combat (Kelley et al., 2013). Reestablishing that connection to other veterans in a higher education setting could lead to increased student persistence and outcomes. National Survey Student Engagement (2010) reported combat veterans to be less engaged with faculty and sought little support while on campus. To promote more engagement and access to support services, I suggest that student peers who are also veterans be considered for the role of a navigator or guide to other student veterans in this space. Navigators should be capable of assisting with the development of an enrollment plan tailored to each veteran's specific set of needs, academic goals, and menu of veterans' benefits available to them while enrolled.

Student affairs administrators at community colleges throughout the country should give thoughtful consideration to this research and to their policies and procedures related to student veterans on campus, in particular those who have experienced combat. Such administrators should provide opportunities for all faculty, staff, and fellow students to gain a better understanding of student combat veterans in support of their overall persistence and successful academic outcomes. 


\section{REFERENCES}

Ackerman, R., DiRamio, D., \& Mitchell, R. L. (2008). From combat to campus: Voices of student-veterans. NASPA Journal, 45(1), 73-102.

Briggs, B. (2012, July 2). Thousands of veterans failing in latest battlefield: College. Retrieved from http://usnews. nbcnews.com/_news/2012/07/02/1 2509343-thousands-of-veterans-failing-in-latest- battlefield-college?lite

Birks, M., \& Mills, J. (2011). Grounded theory: A practical guide. Thousand Oaks, CA: Sage.

Burke, P. J., \& Stets, J. E. (2009). Identity theory. New York, NY: Oxford University Press.

Cate, A. (2013). Exploring student veterans' post-secondary completion rates with two national surveys. Student Veterans of America Research Brief, 1(1), 1-5.

Cook, B., \& Kim, Y. (2009, July). From soldier to student: Easing the transition of service members on campus. Washington, DC: American Council on Education.

DiRamio, D., \& Jarvis, K. (2011). Veterans in higher education: When Johnny and Jane come marching to campus. ASHE Higher Education Report, 37(3).

Gee, J. P. (2000). Identity as an analytical lens for research in education. Review of Research in Education, 25, 99-125.

Glaser, B. G., \& Strauss, A. L. (1967). The discovery of grounded theory: Strategies for qualitative research. New York, NY: Aldine.

Golden, D. R., Niles, T. A., \& Hecht, M. L. (2002). Jewish American identity. In J. N. Martin, T. K. Nakayama, \& L. A. Flores (Eds.), Readings in intercultural communication: Experiences and contexts (pp. 44-52). New York, NY: McGraw-Hill.

Goodman, J., Schlossberg, N. K., \& Anderson, J. L. (2006). Counseling adults in transition: Linking practice with theory (3rd ed.). New York, NY: Springer.

Hecht, M. L. (1993). 2002-A research odyssey: Toward the development of a communication theory of identity. Communication Monographs, 60(1), 76-81.

Hecht, M. L., Jackson, R. L., \& Ribeau, S. A. (2003). African American communication: Exploring identity and culture. Mahwah, NJ: Lawrence Erlbaum.

James, W. (1890). Principles of psychology. New York, NY: Holt, Rinehart, and Winston.

Jones, S. R., \& McEwen, M. K. (2000). A conceptual model of multiple dimensions of identity. Journal of College Student Development, 41(4), 405-414.

Kasworm, C. (2003, April 21). What is collegiate involvement for adult undergraduates. Paper presented at a Symposium of the American Education Research Association, Chicago, IL. (ED481228)

Kasworm, C., Polson, C., \& Fishback, S. (2002). Responding to adult learners in higher Education. Malabar, FL: Krieger.

Kelley, B. C., Smith, J. M., \& Fox, E. L. (2013). Preparing your campus for veterans'success. Sterling, VA: Stylus.

Livingston, W., Havice, P., Cawthon, T., \& Fleming, D. (2011). Coming home: Student veterans' articulation of college re-enrollment. Journal of Student Affairs Research and Practice, 48(3), 315-331.

Loss, C. P. (2012). Between citizens and the state: The politics of American higher education in the 20th century. Princeton, NJ: Princeton University Press.

Maxwell, J. A., (2005). Qualitative research design: An interactive approach. Thousand Oaks, CA: Sage.

McBain, L., Kim, Y. M., Cook, B. J., \& Snead, K. M. (2012, July). From soldier to student II: Assessing campus programs for veterans and service members. Washington, DC: American Council on Education.

Minnis, S., \& Hammond, S. (2014). Million records project leaves questions unanswered about veterans' educational success (White paper). Washington, DC: Veterans' Knowledge Community, National Association of Student Personnel Administrators.

National Survey of Student Engagement. (2010). Annual results. Bloomington, IN: Indiana University Center for Postsecondary Research.

Olson, K. W. (1973). The GI bill and higher education: Success and surprise. American Quarterly, 25(5), 596-610.

Olson, K. W. (1974). The GI Bill, the veterans, and the colleges. Lexington, KY: University Press of Kentucky.

Orbe, M. P. (2004). Negotiating multiple identities within multiple frames: An analysis of first-generation college students. Communication Education, 53(2), 131-149.

Rumann, C. B. \& Hamrick, F. A. (2010). Student veterans in transition: Reenrolling after war zone deployments. The Journal of Higher Education, 81(4), 431-58.

Schlossberg, N. K. (1984). Counseling adults in transition. New York, NY: Springer. 
Serow, R. C. (2004). Policy as a symbol: Title II of the 1944 G.I. bill. The Review of Higher Education, 27(4), 481-499. Strauss, A. L., \& Corbin, J. M. (1998). Basics of qualitative research: Techniques and procedures for developing grounded theory. Thousand Oaks, CA: Sage.

Titus, C. H. (1944). The university and the new veteran. The Journal of Higher Education, 15(2), 71-78, 116.

U.S. Department of Veterans Affairs (2010). RCS Report. Washington, DC: U.S. Department of Veterans Affairs.

Wood, D. (2012, October 25). Veterans' college dropout rate soars. Huffington Post. Retrieved from http://www. huffingtonpost.com/2012/10/25/veterans-college-drop-out_n_2016926.html 